\title{
A case of duodenal Brunner's gland adenoma
}

\author{
Min Xie ${ }^{1}$, Hong Tang ${ }^{2}$ \\ ${ }^{1}$ Department of Imaging, ${ }^{2}$ Department of Pathology, Nanjing Medical University Affiliated Wuxi Second Hospital, Wuxi, China \\ Correspondence to: Hong Tang. Department of Pathology, Nanjing Medical University Affiliated Wuxi Second Hospital, 68 Zhongshan Road, Wuxi \\ 214002, China. Email: wxey6103@163.com.
}

Submitted Feb 24, 2020. Accepted for publication Apr 16, 2020.

doi: 10.21037/hbsn-20-319

View this article at: http://dx.doi.org/10.21037/hbsn-20-319

A 52-year-old man presented with recurrent right upper quadrant pain of $>10$ months' duration. His abdomen was soft, with no tenderness or rebound tenderness. Laboratory tests showed increased white blood cells, serum amylase and lipase levels, and erythrocyte sedimentation rate. Computed tomography revealed obvious thickening of the wall of the second portion of the duodenum by a soft tissue mass showing contrast enhancement (Figure 1A-C).
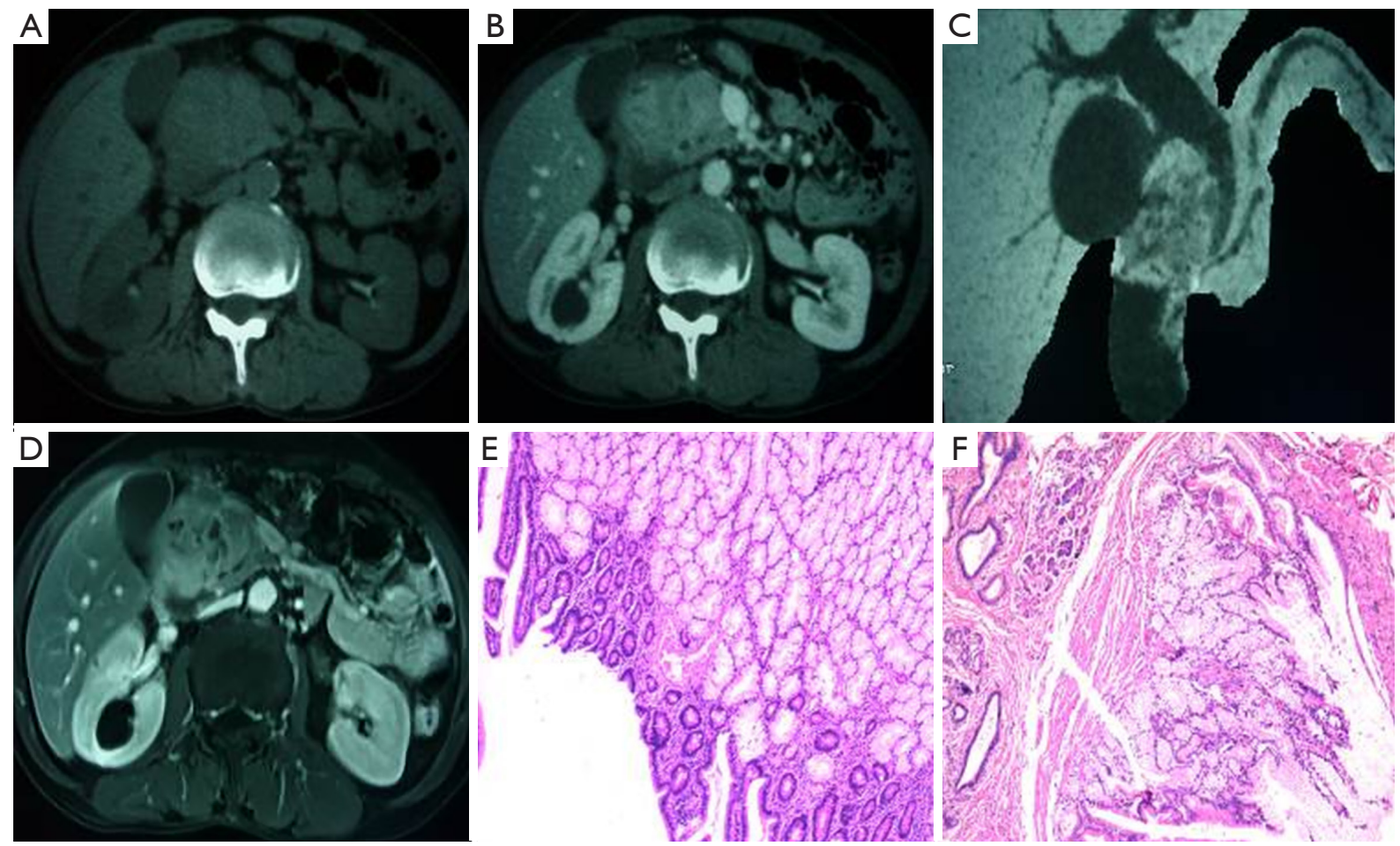

Figure 1 Images of Brunner's gland adenoma. (A) Unenhanced computed tomography axial image showing a soft tissue mass with indistinct margins in the second portion of the duodenum. (B) Axial image in the portal venous phase showing continued heterogeneous enhancement of the mass with interspersed fluid-density areas. (C) Computed tomography cholangiopancreatography image showing the relatively sharp margins of the mass, and the arc of the pressure trace on the common bile duct. (D) Contrast-enhanced T1-weighted image showing significant heterogeneous enhancement of the mass. (E) Photomicrograph showing large areas of hyperplastic fat acini in the lesion, with abundant eosinophilic cytoplasm and small round nuclei in the basilar part of each acinus $(\times 40)$. (F) Photomicrograph showing pancreatic ducts and lobules in the muscular layer of the intestinal wall within the lesion $(\times 100)$. 
Magnetic resonance imaging revealed a $3.1 \times 3.7-\mathrm{cm}$ duodenal mass, with significant contrast enhancement, and dilatation of the intrahepatic bile ducts, common hepatic duct, and proximal common bile duct (Figure $1 D)$. During pancreaticoduodenectomy, we resected a palpable, soft, moveable duodenal mass measuring $5 \times 6 \times 2$ $\mathrm{cm}$. Histology showed large areas of hyperplastic fat acini with abundant eosinophilic cytoplasm. Smooth muscle was interspersed between the acini, and nodules were present (Figure 1E,F). We diagnosed Brunner's gland adenoma.

\section{Acknowledgments}

Funding: None.

\section{Footnote}

Provenance and Peer Review: This article is a free submission to the editorial office, Hepatobiliary Surgery and Nutrition. The article did not undergo external peer review.

Cite this article as: Xie M, Tang H. A case of duodenal Brunner's gland adenoma. HepatoBiliary Surg Nutr 2020;9(6):820821. doi: 10.21037/hbsn-20-319
Conflicts of Interest: Both authors have completed the ICMJE uniform disclosure form (available at http://dx.doi. org/10.21037/hbsn-20-319). The authors have no conflicts of interest to declare.

Ethical Statement: The authors are accountable for all aspects of the work in ensuring that questions related to the accuracy or integrity of any part of the work are appropriately investigated and resolved. Written informed consent was obtained from the patient for publication of this manuscript and any accompanying images.

Open Access Statement: This is an Open Access article distributed in accordance with the Creative Commons Attribution-NonCommercial-NoDerivs 4.0 International License (CC BY-NC-ND 4.0), which permits the noncommercial replication and distribution of the article with the strict proviso that no changes or edits are made and the original work is properly cited (including links to both the formal publication through the relevant DOI and the license). See: https://creativecommons.org/licenses/by-nc-nd/4.0/. 